\title{
PROCES SUŠENJA ORAHA
}

\section{WALNUT DRYING PROCESS}

\author{
Đorđije DODER, Damir ĐAKOVIĆ, \\ Faculty of Technical Sciences, Novi Sad, Serbia, \\ dj.doder@uns.ac.rs
}

\begin{abstract}
U ovom radu analiziran je postupak tretmana oraha koji se izlažu sušenju. Sugerisani su dijagrami tokova, kako za ceo proces koji uključuje i pripremne operacije, tako i za numeričku analizu posmatranog problema, koja je neophodna da bi se dobili preliminarni rezultati matematičkog modela procesa sušenja oraha. Detaljnije je objašnjena numerička strategija, kao i različiti metodi sušenja $i$ skladištenja. Ovakva analiza problema pruža uopštenu sliku procesa sušenja, što može da omogući bolji uvid u partikularne probleme i pouzdanije planiranje procesa.
\end{abstract}

Ključne reči: Sušenje oraha, Modelovanje, Dijagram toka

In this paper is analised the process of walnut drying. The flow-charts, for the whole process including pre-drying operations, as well as for numerical solving process are proposed, since the convenient procedure of numerical solving has to take place for the better problem insight. Drying methods, as well as storage principles, are described in more detail. This type of problem analysis could provide more general review of overall drying process, which results in more reliable process planning.

Key words: Walnut drying, Modeling, Flow-chart

\section{Introduction}

Walnut (Juglans Regia L) is a very important nut type, which has a very high nutrient quality. For optimal quality, nuts have to be treated with care by means of harvesting, drying, storage and transporting. There are a number of ways for caring out all of these items, but experiences and practice through the decades of walnut cultivation showed there are approaches that gave the best results. Some of these approaches are shown in literature $[1,2,3]$. Different walnut varieties show different physical characteristics and some of the most famous varieties are Chandler, Howard, K82, Serr and others. In Serbia, there are a few domestic varieties such as Novosadski kasni, Srem, Tisa and others. Prescribed quality of inshell walnuts are formed by United Nations organs by standard "UNECE STANDARD DDP-01, Inshell Walnuts" [4]. According to this standard walnut quality can be classified in three categories. Walnut production on a large scale is mostly related to China, USA, Iran and Turkey. However, Persian walnut is still considered as a traditional product of agriculture of Balkans and Central Asia regions. In the former state union of Serbia and Montenegro annual yield is estimated at 21547 tons per year or approximately $2 \mathrm{~kg}$ per capita. These data were taken from [5].

In comparison to plum or apple growing, despite excellent ecological conditions, walnut grow in Serbia is not at satisfactory level.

\section{General walnut drying process features}

In this paper a global analysis of walnut drying process is proposed and it's shown by a convenient flow-chart. This flow-chart is created by analyzing the available literature $[1,2,3,6]$, keeping in mind that some drying techniques are recommended through the corresponding literature and that the advantage has been given to some approaches over the others.

\subsection{Brief review of walnut drying requirements}

Initial moisture content of fresh harvested walnuts can wary in a wide range, which primarily depends on harvesting time. Early harvested walnuts have higher moisture content while walnuts that have fallen from a tree have smaller moisture content. The moisture is mostly contained in the outer hull, so walnuts in hull must undergo a longer drying process. Satisfactory level of final moisture content is usually taken as $8 \%$ of moisture on dry basis of walnut mass. Equilibrium moisture content (EMC) information is of a large significance. For instance authors [7] have proposed the next relations for EMC estimation: 


$$
\log \left[\log \left(\frac{1}{1-r h}\right)\right]=1.77 \log \left(M_{e}\right)-2.05
$$

Long-term exposure of walnuts to temperatures larger than $43^{\circ} \mathrm{C}$ may cause the walnuts to become rancid. Short-term exposure to higher temperatures, even those that are extremely high, should not cause such an advent, but the experiments [8] showed that this approach doesn't decrease drying time almost at all. Furthermore, it causes high-temperature damage of shell.

\subsection{Drying and storage tehniques}

Among many nuts drying tehniques, according to literature [3], the most reliable once are: sun drying (natural drying), solar drying, bin drying and vertical cylinder drying (artificial drying).

Considering all relevant parameters (investement and operating cost, drying time efficiency, facility construction complexity) bin drying system is the most appropriate one. For walnuts storage, dry low temperature places are recommended. The most noticeable indicator of spoiled walnuts is the rancid taste. Most preferable storage systems are bagged, silo, low-temperature, airtight and aerated systems [6]. Finally, the mentioned flow-chart is showed at Fig. 1:

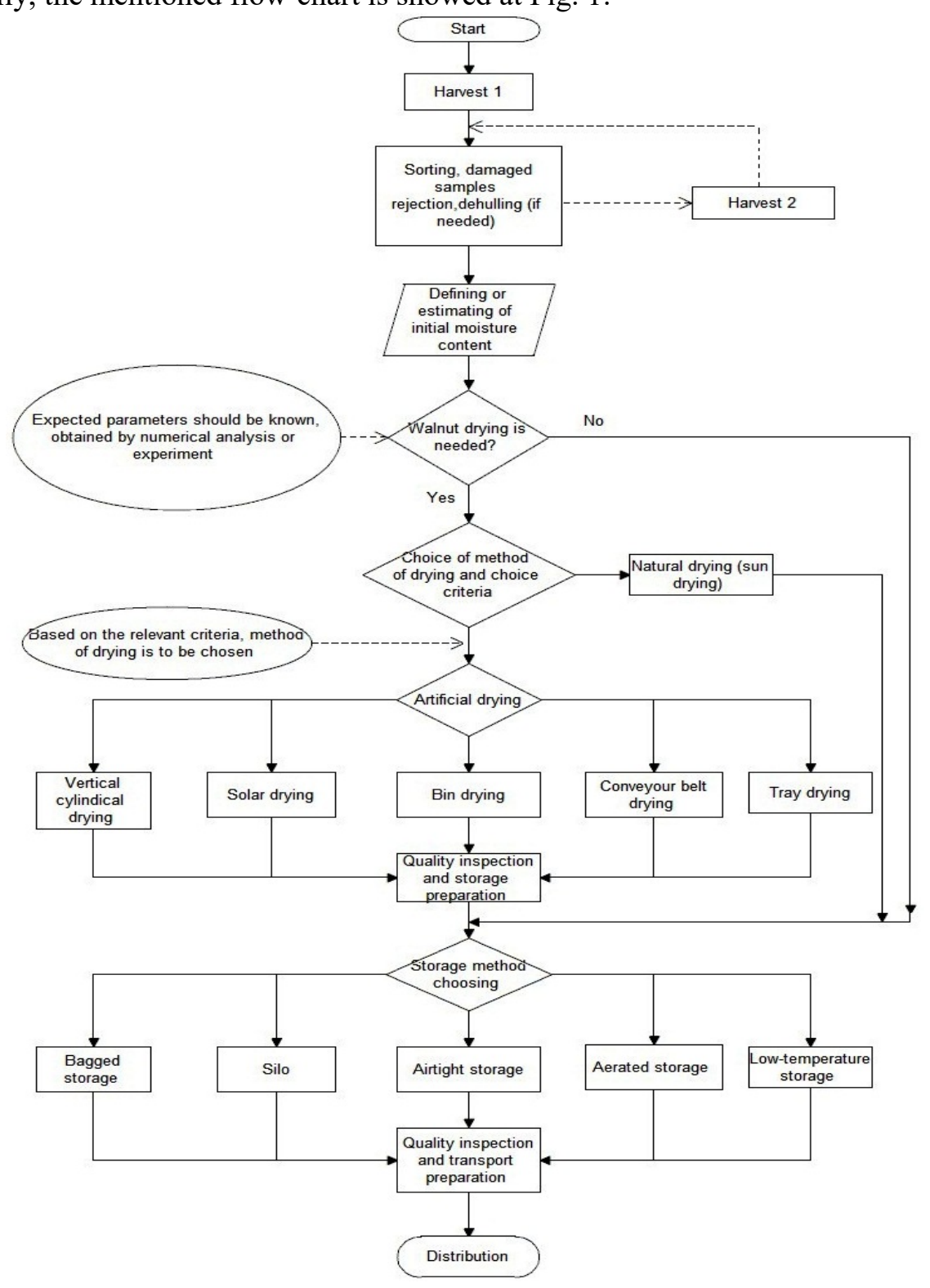

Fig. 1. Flow-chart for walnut drying process 


\section{Mathematical model and numerical analysis of bin drying systems}

Generally, for simulation of drying process of nuts (and grain materials as well) the thin layer drying model is used. There are several approaches for thin layer drying mathematical description, but for walnuts the Page's model is the most reliable one. When effects of TLD are known, one can access to deep bed drying modeling where the mass and heat balances of moisture and air (as the drying agent) are included. This kind of model is hard for analytical solving so the numerical approach is used (finite difference method). Because of the relatively long time of deep bed walnuts drying, time step of one minute was used. Spatial discretization is set up so the one spatial step is equal to $1 \mathrm{~cm}$. This kind of mathematical model is used for numerical simulation, and is also proposed by the authors [9]. It can be written as follows.

Heat balance:

$$
\frac{\partial T}{\partial t}=\frac{-G_{a}\left(c_{a}+c_{v} X\right)}{\rho_{p}\left(c_{p}+c_{w} M\right)} \frac{\partial T}{\partial x}-\frac{G_{a} h_{f g}}{\rho_{p}\left(c_{p}+c_{w} M\right)} \frac{\partial X}{\partial x}
$$

Mass balance:

$$
\frac{\partial X}{\partial x}=\frac{-\rho_{P}}{G_{a}} \frac{\partial M}{\partial t}
$$

Drying rate equation:

$$
\frac{\partial M}{\partial t}=-k\left(M-M_{e}\right)
$$

Where $\mathrm{k}$ is experimentally obtained drying rate coefficient and can be expressed as:

$$
k=\exp \left(-0.681+0.11 M_{o} 0.952 \ln M_{o}+0.000152(1.8 T+32.2)^{2}\right.
$$

Thermal and physical properties of walnuts that are used for this model were taken from literature $[10,11]$ for English walnuts and K82 variety:

Table 1: Thermal and physical properties of walnuts

\begin{tabular}{||l|c|c|c||}
\hline \hline Process parameter & \multicolumn{1}{|c|}{ Unit } & Value & Note \\
\hline Diameter, $\mathrm{D}$ & $\mathrm{mm}$ & 35 & K82 variety \\
\hline Specific heat dry air, $\mathrm{Cpa}$ & $\mathrm{kJ} /(\mathrm{kgK})$ & 1.01 & general \\
\hline Density of dry air, $\rho$ & $\mathrm{kg} / \mathrm{m}^{3}$ & 588 & average \\
\hline Specific heat dry solids, $\mathrm{Cp}$ & $\mathrm{kJ} /(\mathrm{kgK})$ & 1.26 & general \\
\hline Initial walnut temperature, $\mathrm{Tg}$ & $\mathrm{K}$ & 303 & ambient \\
\hline Initial walnut moisture, $\mathrm{M}_{0}$ & $\% \mathrm{~d} . \mathrm{b}$. & 39.76 & K82 variety \\
\hline Inlet air temperature, $\mathrm{Ta}$ & $\mathrm{K}$ & 315 & ambient \\
\hline Inlet air relative humidity, $\mathrm{rh}$ & $\%$ & 40 & ambient \\
\hline Inlet air pressure, $\mathrm{p}_{\mathrm{a}}$ & $\mathrm{Pa}$ & 101325 & ambient \\
\hline Distance step, $\Delta \mathrm{x}$ & $\mathrm{cm}$ & 1 & \\
\hline Time step, $\Delta \mathrm{t}$ & $\mathrm{min}$ & 1 & \\
\hline \hline
\end{tabular}

The numerical strategy for model solving is shown through the following flow-chart, at Fig. 2: 


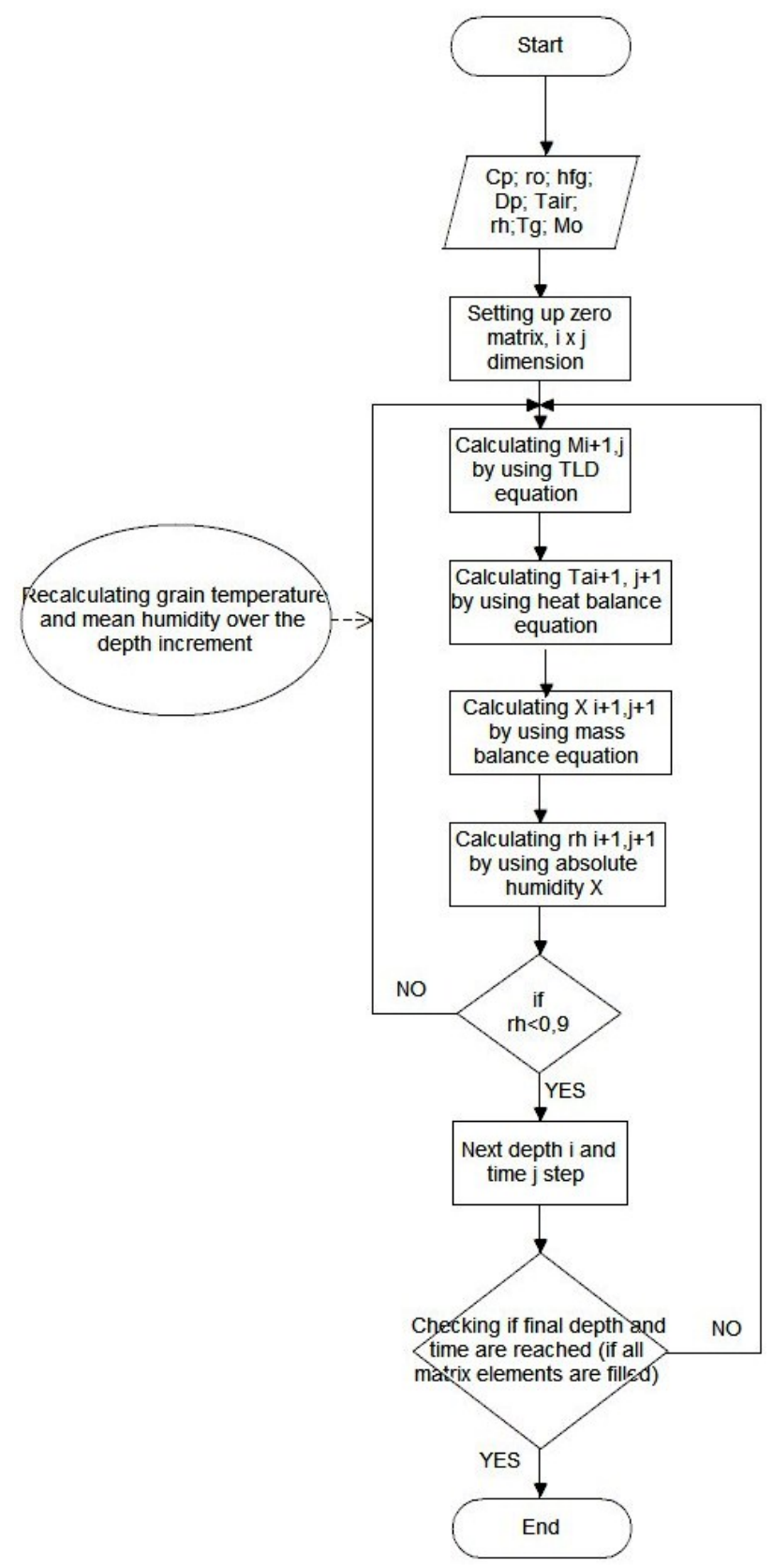

Fig. 2. Flow-chart for numerical analysis

\section{Numerical results analysis}

Numerical simulation was made by using Matlab code, which was prepared according to the mentioned procedure. Bed depth was $0.5 \mathrm{~m}$, and total drying time $30 \mathrm{~h}$. As showed in Fig. 3 (left), it takes about $16 \mathrm{~h}$ for the process to decrease its average moisture content below $1 \%$ of moisture (dry basis). For the entire drying process, falling drying rate appears (right): 

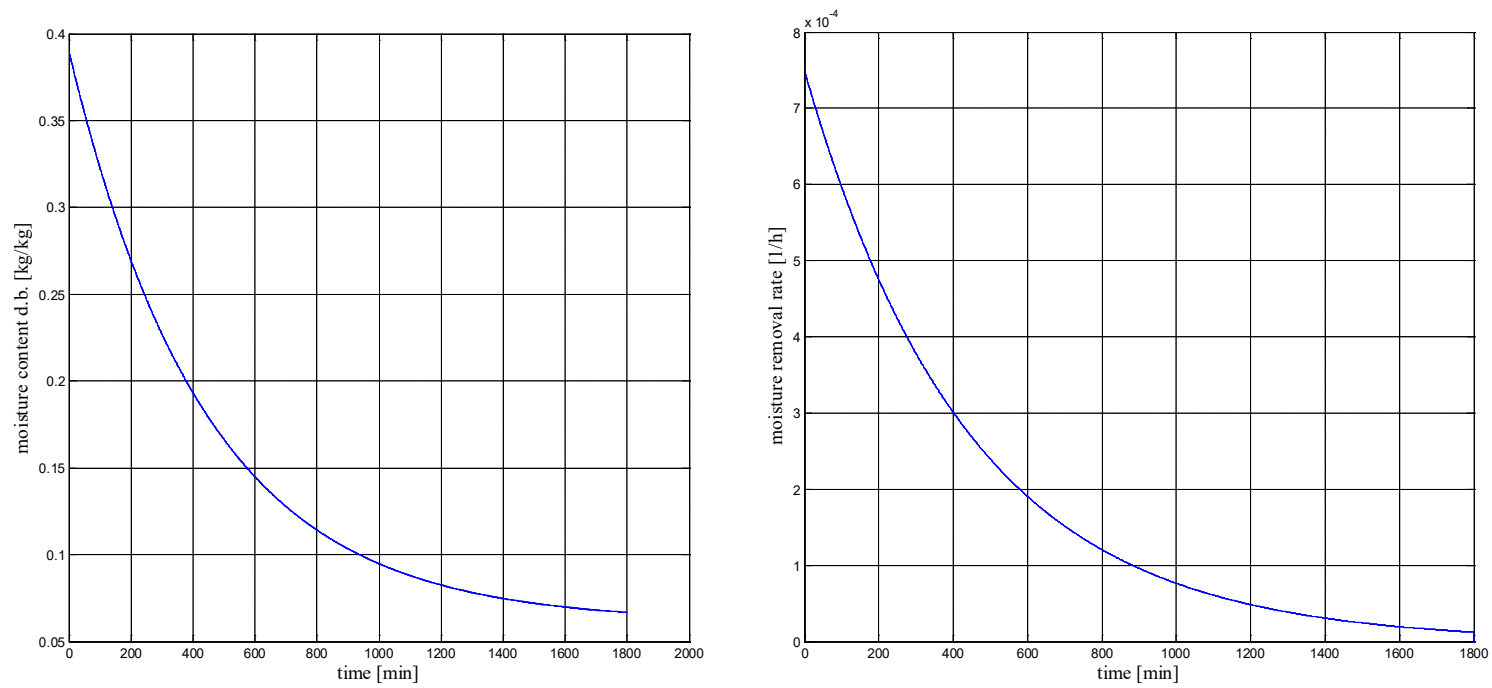

Fig. 3. Average moisture content $M$ (left) and moisture removal rate $d M / d t$ (right) during the drying of deep bed

\section{Conclusion}

The drying approach proposed in this paper is similar to those that are used for any other grain drying (wheat, corn, rice, etc.). This mathematical model and obtained results of numerical simulation can serve as a base for the future numerical and experimental analyzing of nuts dehydration processes. Based on the literature survey it can be concluded that there are no such results for walnut cultivars in Serbia, while internationally published results are also pretty poor. Developing such numerical approaches with different discretization algorithms might result in even more accurate information. Anyway, the mentioned results gave the satisfactory concurrence and can give a good insight to a walnut drying process phenomena. In this paper the approach for synthesis of important sub-processes is proposed, so the overall process observation could be simplified. That could provide a better environment for more frequent investigation, designing and investing in walnut cultivation and post-processing actions.

\section{Nomenclature}

Marks:

$T$ - temperature $\left[{ }^{\circ} \mathrm{C}\right]$

$t$ - time $[\mathrm{s}]$

$G-$ mass flow rate $\left[\mathrm{kg} / \mathrm{s} \cdot \mathrm{m}^{2}\right]$

$c$ - specific heat $[\mathrm{J} / \mathrm{kgK}]$

$\rho$-density $\left[\mathrm{kg} / \mathrm{m}^{3}\right]$

$X-$ absolute humidity $[\mathrm{kg} / \mathrm{kg}]$

$x$ - depth coordinate $[\mathrm{m}]$

$h_{f g}$ - latent heat $[\mathrm{J} / \mathrm{kg}]$

$M$ - moisture content [ $\%_{\text {dry basis }}, \mathrm{kg} / \mathrm{kg}$ ]

$\mathrm{Me}$ - equilibrium moisture content [\%, $\mathrm{kg} / \mathrm{kg}]$

$r h$ - relative humidity [\%]

$V$ - volume $\left[\mathrm{m}^{3}\right]$

$r$-radius [m]

Indexes:

$i$ - space increment mark

$j$-time increment mark

d.b. - dry basis

$a-$ air 
$p$-product, material

$v$-vapor

$w$ - water

\section{References}

[1] Kashani Nejad M., et al., Effect of Drying Methods on Quality of Pistachio Nuts, Drying Technology Vol. 21, No. 5, pp. 821-838, 2003

[2] Wiegand, E.H., Walnut Drying and Packing in Oregon, Oregon State Agricultural College, 1927 Station Bulletin

[3] Shakerardekani A., et al., Types of Dryers and Their Effect on the Pistachio Nuts Quality-a Review, Journal of Agricultural Science, Vol 3., No. 4, pp 13-21, 2011

[4] ***, UNECE STANDARD DDP-01concerning the marketing and commercial quality control of INSHELL WALNUTS, 2010 edition, UNITED NATIONS New York and Geneva, 2010

[5] ***, Moć Prirode, Edicija Priroda i zdravlje - Jezgrasto voće, Gajenje i upotreba, "Potez" Novi Beograd, br. 63, pp 14-27, 2006

[6] Bala B.K., Drying and Storage of Cereal Grains, Second Edition, John Wiley and Sons, 2017

[7] Rumsey T., et al., Equilibrium moisture of walnut cultivars, Sacramento, CA: Walnut Research Reports. Walnut Marketing Board, 1997

[8] Rumsey T., Lu Z., High temperature walnut drying, Sacramento, CA: Research report. Walnut Marketing Board, 1991

[9] Rumsey T., Thompson J., Ambient Air Drying of English Walnuts, Transactions of ASAE, Vol 27., No.3, pp 942-945, 1984

[10] Hassan-Beygi S. R., et al., Drying characteristics of walnut (Juglans regia L.) during convection drying, International Agrophysics, Vol 23, pp 129-135, 2009

[11] Rumsey T., Arthur J.F., Two-dimensional Drying Model for Stationary Bin Walnuts Dryers, Transactions of ASAE, Vol 34(1)., No.3, pp 193-200, 1991 